\title{
Meaning of Wenzel Jamnitzer's treatise Perspectiva corporum regularium (Nürnberg, 1568) and its relationship to history of modern science
}

\author{
J. Fábry \\ Institute of Physics, Academy of Sciences of the Czech Republic, v.v.i., Na Slovance 2, 18221 Praha 8, Czech Republic
}

The contribution aims at explanation of the meaning of Jamnitzer's work [see also 1], especially elucidation of the relationship between the perspective, i.e. the method how the visual perception of the world can be mathematized, and five regular (Platonic) solids. Four elements, i.e. Fire, Air, Earth and Water, have been traditionally attributed to the tetrahedron, octahedron, cube and icosahedron, respectively (Plato's Timaios). The dodecahedron symbolized the Fifth essence or Universe or God's substance by Jamnitzer's own words.

Jamnitzer intended to treat natural phenomena by combinations of the elements following Plato's Timaios. It is manifested by depiction of the regular bodies and their transformations about their common symmetry elements in aesthetically appealing engravings. However, in agreement with the Christian creed, this view about the world goes beyond its visible part. Jamnitzer's work can be interpreted that invisible world can be understood at least at part by adopting geometry and arithmetic which is a way how a human being can get closer to the Creator.

Wenzel Jamnitzer's work was one of the treatises of this kind which were published between $15-17^{\text {th }}$ centuries [2]. This means that his work can be considered as a representative of the culture which was flourishing at that time. Among his predecessors were such important personalities like Luca Pacioli/Leonardo da Vinci (the manuscript De divina proportione, 1498-1499) and Albrecht Dürer, author of Underweysung der Messung, mit dem Zirckel und richtscheyt, in Linien, Ebnen und gantzen Corporen, Nürnberg (1525) who was also a Nürnberger citizen and a goldsmith at the very beginning of his career likewise Jamnitzer himself. Jamnitzer's work shares similarities with Leonardo's illustrations to Luca Pacioli's treatise. It should be emphasized that Nürnberg was a centre of crafts as well as of German/transalpine humanism [1], [3] and it seems not to be coincidence that it was just there where Copernicus's book De revolutionibus orbium coelestium libri VI was printed in 1543 by a famous printer Johannes Petreius.

The ideas which are manifested in the discussed Jamnitzer's work have been reflected in Johannes Kepler's books, i. $a$. in Mysterium cosmographicum or in Strena seu de nive sexangula (Francfurt a. M., 1611), the treatise so important for crystallography. Other examples of the applications of these ideas in architecture - see e.g. [4], [5] - and in arts - e.g. [6] will be shown. Importance of measurement as a method how to approach to the surrounding world will be emphasized in the contribution.

[1] Albert FLOCON (1993). Preface to translation into Spanish by Elena del Amo: Wentzel JAMNITZER, Perspectiva corporum regularium, Nürnberg 1568. Spain: Edición Siruela.

[2] Kirsti ANDERSEN (2007). The Geometry of an Art: The History of the Mathematical Theory of Perspective from Alberti to Monge, p. 212 and p. 224, New York: Springer.

[3] Martin KEMP (1990). The Science of Art. Optical themes in western art from Brunelleschi to Seraut, p. 63. New Haven and London: Yale University Press.

[4] John G. Hatch, The Science Behind Francesco Borromini's Divine Geometry, pp. 127-139 in Nexus IV: Architecture and Mathematics, eds. Kim Williams and Jose Francisco Rodrigues, Fucecchio: Florence: Kim Williams Books, 2002.

[5] George L. Hersey (2000). Architecture and Geometry in the Age of the Baroque. The University of Chicago Press: Chicago.

[6] Miguel Falomir, Lynn Roberts, Paul Mitchell (2017). Arcimboldo. Las Floras y la Primavera. Museo de Bellas Artes: Bilbao.

\section{Keywords: Wenzel Jamnitzer, perspective and geometry, Luca Pacioli, Leonardo, Johannes Kepler}

The author thanks the Institute of Physics for the support. 